\title{
LARGE SPRINGS IN THE VALLEY AND RIDGE PHYSIOGRAPHIC PROVINCE OF PENNSYLVANIA
}

A Contribution to the Appalachian Valleys--Piedmont Regional Aquifer-System Analysis Study

by David $A$. Saad and Daniel J. Hippe

U.S. GEOLOGICAL SURVEY

Open-File Report 90-164

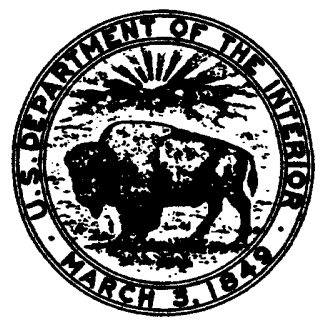

Harrisburg, Pennsylvania 


\title{
DEPARTMENT OF THE INTERIOR, \\ MANUEL LUJAN, JR., Secretary
}

\author{
U.S. GEOLOGICAL SURVEY \\ Dallas L. Peck, Director
}

For additional information write to:

District Chief

U.S. Geological Survey, WRD 4th Floor, Federal Building

P.0. Box 1107

Harrisburg, Pennsylvania 17108-1107
Copies of this report can be purchased from:

U.S. Geological Survey

Books and Open-File Reports Section Federal Center

Box 25425

Denver, Colorado 80225 


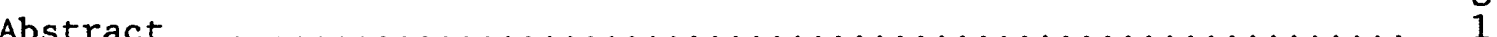

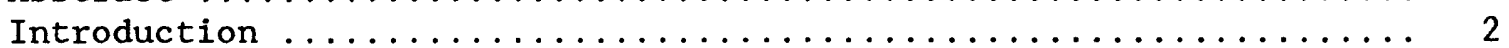

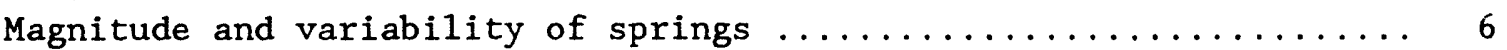

Types of springs ............................. 8

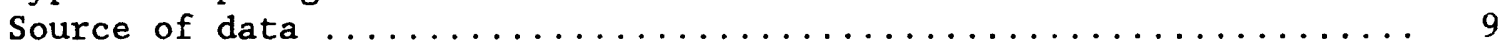

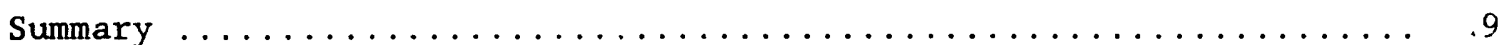

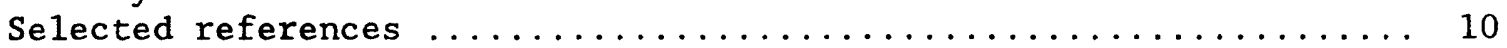

\section{ILLUSTRATIONS}

Figure 1.--Map showing the Appalachian Valleys-Piedmont Regional Aquifer-System Analysis study area, physiographic provinces, and area studied in this report ..........

2.--Map showing the location and magnitude of large springs in the Valley and Ridge physiographic province of

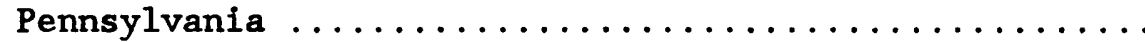

3.--Histogram of the magnitude of springs in the Valley and Ridge physiographic province of Pennsylvania for springs with single or median discharge values greater than 100 gallons per minute $\ldots \ldots \ldots \ldots \ldots \ldots$

\section{TABLES}

Table 1.--Classification of springs with respect to discharge ....

2.--Records of the large springs in the Valley and Ridge physiographic province of Pennsylvania 


\section{CONVERSION FACTORS AND ABBREVIATIONS}

For the convenience of readers who may prefer metric (International system) units rather than the inch-pound units used in this report, the following conversion factors may be used:

Multiply Inch-Pound Unit

mile (mi)
cubic foot per second $\left(\mathrm{ft}^{3} / \mathrm{s}\right)$
gallon per minute (gal/min)

By

\section{To obtain Metric Unit}

Length

1.609

kilometer (km)

Flow

0.02832

cubic meter per second $\left(\mathrm{m}^{3} / \mathrm{s}\right)$

0.06308

liter per second $(\mathrm{L} / \mathrm{s})$ 


\title{
LARGE SPRINGS IN THE VALLEY AND RIDGE PHYSIOGRAPHIC PROVINCE OF PENNSYLVANIA
}

by David A. Saad and Daniel J. Hippe

\begin{abstract}
In the Valley and Ridge physlographic province of Pennsylvania, 137 springs have a single or median discharge value equal to or greater than 100 gallons per minute. Information for these large springs has been tabulated to summarize the data useful to the U.S. Geological Survey's Appalachian Valleys--Piedmont Regional Aquifer-System Analysis study. Among the springs measured or estimated to date (1989), 39 are of the fourth magnitude (100 to 449 gallons per minute), 83 of the third magnitude ( 449 to 4,490 gallons per minute), 15 of the second magnitude $(4,490$ to 44,900 gallons per minute), and none of the first magnitude (greater than 44,900 gallons per minute). There are 123 springs that discharge from carbonate rocks, 9 from clean sandstone, 3 from shale and other interbedded rock types, and 2 from unconsolidated material.
\end{abstract}




\section{INTRODUCTION}

This report presents discharge data and other information on 137 large springs in the Valley and Ridge physiographic province. This information will be used for the U.S. Geological Survey's Appalachian Valleys--Piedmont Regional Aquifer-system Analysis (APRASA) study, an investigation of the quantity and quality of ground-water resources in the Valley and Ridge, Blue Ridge, and Piedmont physiographic provinces (fig. 1). The data available from these springs provide insight into the ground-water systems with which they are associated. The types of flow systems, size of drainage areas, and types of rock are some of the information about the ground-water systems associated with springs that may be hypothesized using the available data.

Large springs are defined in this report as those springs with a discharge equal to or greater than 100 gal/min (gallons per minute). Most of the large springs in Pennsylvania are in the Valley and Ridge physiographic province (fig. 2). This province extends northeastward from the south-central to the east-central borders of Pennsylvania in an arc that is about $70 \mathrm{mi}$ (miles) wide.

Water from springs has been, and is, used for a wide variety of purposes. These include fish hatcheries, stock supply, industry, irrigation, cooling, and recreation. Many springs are used either as the primary or supplemental source of water for municipal supplies. 


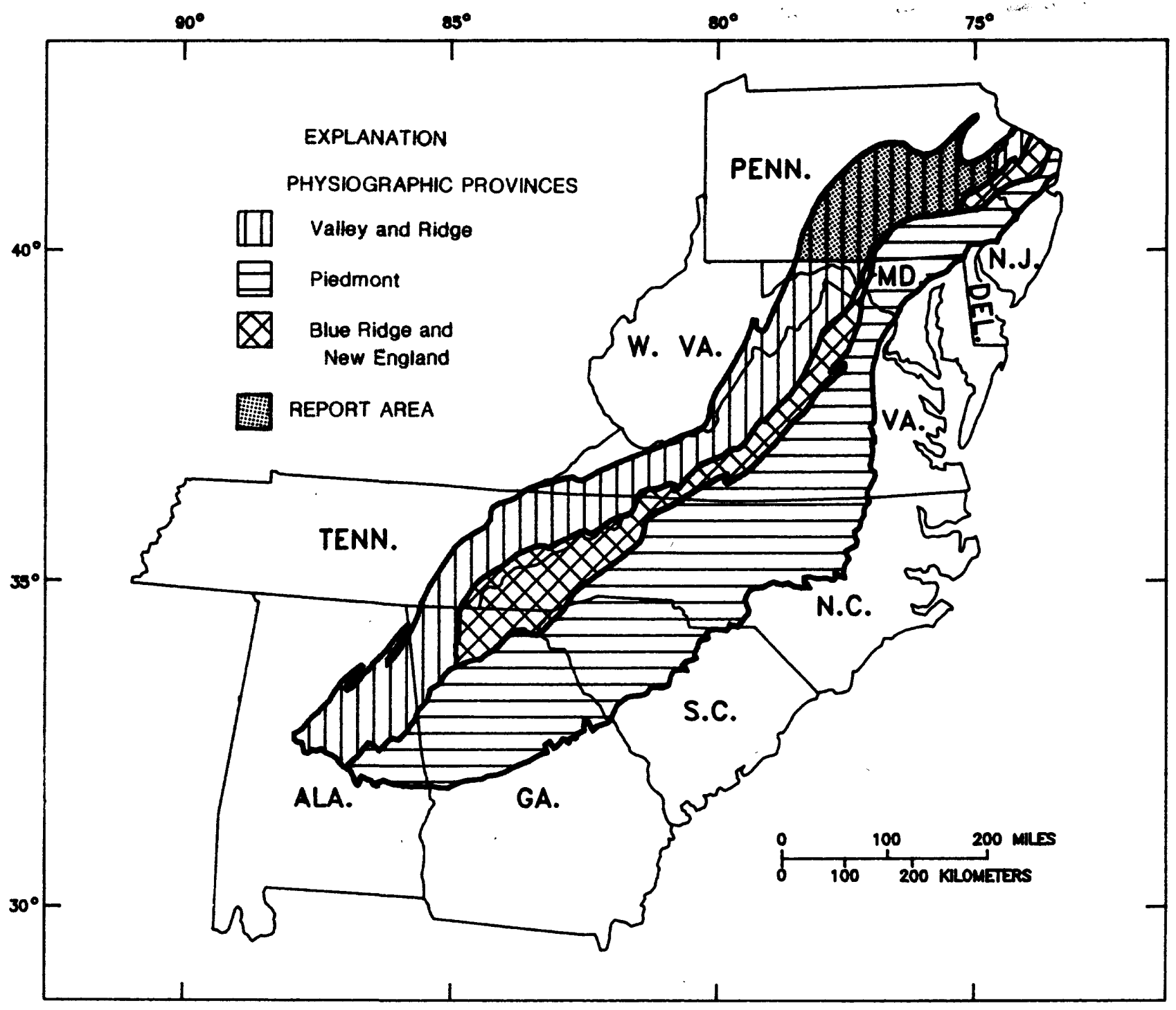

Figure 1.--The Appalachian Valleys-Piedmont Regional Aquifer-System Analysis study area, physiographic provinces, and area studied in this report. 


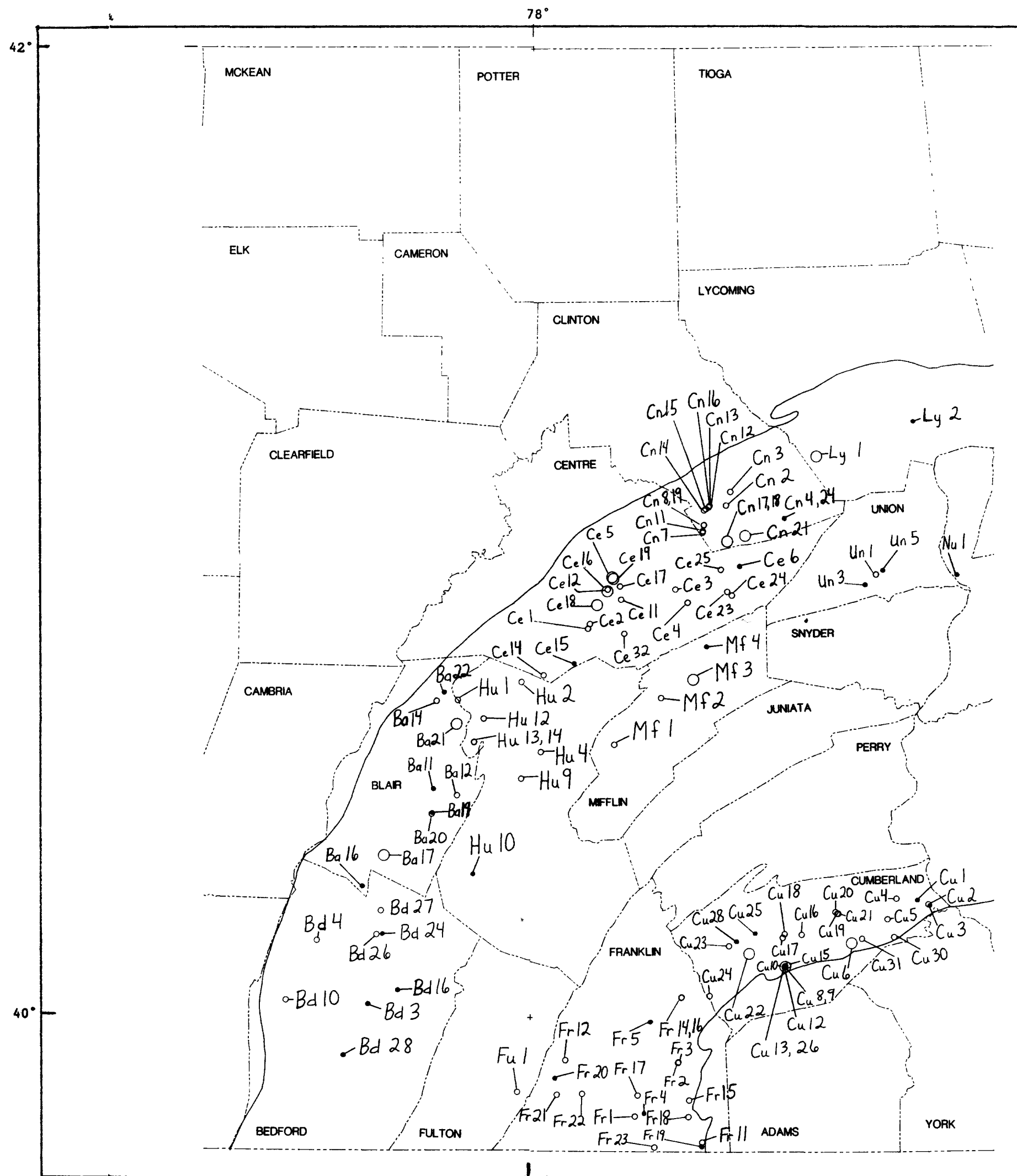

Figure 2.--Location and magnitude of large springs in the 


\section{MAGNITUDE AND VARIABILITY OF SPRINGS}

Discharge from springs of the Valley and Ridge physiographic province of Pennsylvania range in size from less than 1 gal/min to greater than 10,000 gal/min. Discharges of individual springs vary both daily and seasonally. This report contains information on springs that have a single or median discharge equal to or greater than 100 gal/min. According to the classifications of Meinzer (1927), only springs of the fourth, third, and second magnitude are included (table 1 ).

The location and magnitude of the large springs in the Valley and Ridge physiographic province of Pennsylvania are shown in figure 2. Figure 3 is a frequency distribution of the size of springs in the Valley and Ridge physiographic province of Pennsylvania.

Pennsylvania has no springs of the first magnitude on the basis of median discharge. Discharges of some of the larger springs in the Valley and Ridge physiographic province do vary greatly however, and some instantaneous discharges greater than $44,900 \mathrm{gal} / \mathrm{min}$ have been reported. Nippono Spring (Ly 1) in Lycoming County, which has a median discharge of $18,000 \mathrm{gal} / \mathrm{min}$ (F1ippo, 1974), has a reported instantaneous discharge of $66,300 \mathrm{gal} / \mathrm{min}$. Large variations in discharge are characteristic of conduit flow systems and are discussed in detail in the next section. Large variations in discharge a1so are characteristic of surface streams that enter the subsurface through sinkholes or caves. A conduit spring, such as Arch Spring (Ba 21) in Blair County, that receives recharge from such streams also will have large variations in discharge.

There are 15 springs of the second magnitude in the Valley and Ridge physiographic province. Of these, Boiling Springs ( $\mathrm{Cu}$ 6) in Cumberland County has been reported by Meinzer (1927) to be the largest spring in Pennsylvania. However, on the basis of median discharge, Flippo (1974) reported Nippono Spring (Ly 1), in Lycoming County, to be the largest spring in Pennsylvania. There are 83 springs of the third magnitude in the Valley and Ridge physiographic province of Pennsylvania and 39 springs of the fourth magnitude.

A11 springs exhibit some seasonal variability. Some springs have relatively little variance; however, others, such as Rock Spring (Ce 14), have discharges that vary from $225 \mathrm{gal} / \mathrm{min}$ to possibly $11,200 \mathrm{ga} / \mathrm{min}$. Most of the springs in Pennsylvania do not have continuous records of discharge; therefore, seasonal variability poses a problem when categorizing springs into groups if limited numbers of discharge measurements are available. A single instantaneous discharge measurement probably will not accurately represent the average discharge of a spring and gives no clue to its variability. Additionally, multiple instantaneous discharge measurements also may not be representative of the average discharge and variability in discharge. Multiple measurements made at a spring under non-normal climatic conditions may not be representative of the discharge and variability under normal conditions. 
Table 1.--Classification of springs with respect to discharge [modified from Meinzer, 1927; gal/min, gallons per minute]

Magnitude

Range of discharge (median values) 1

First

Second

Third

Fourth

Fifth

Sixth

Seventh

Eighth

$$
\begin{array}{rrr}
44,900 & \mathrm{gal} / \mathrm{min} \text { or more } \\
4,490 & \text { to } 44,900 \mathrm{gal} / \mathrm{min} \\
449 & \text { to } 4,490 \mathrm{gal} / \mathrm{min} \\
100 & \text { to } & 449 \mathrm{gal} / \mathrm{min} \\
10 & \text { to } & 100 \mathrm{gal} / \mathrm{min} \\
1 & \text { to } & 10 \mathrm{gal} / \mathrm{min} \\
0.125 & \text { to } & 1 \mathrm{gal} / \mathrm{min} \\
\text { Less than } 0.125 \mathrm{gal} / \mathrm{min}
\end{array}
$$

Leinzer defined spring magnitudes based upon an average (mean) value for discharge measurements. For this report the classifications have been applied to single or median discharge values of more than one instantaneous discharge measurement.

Figure 3.--Histogram of the magnitude of springs in the Valley and Ridge physiographic province of Pennsylvania for springs with single or median discharge values greater than 100 gallons per minute.

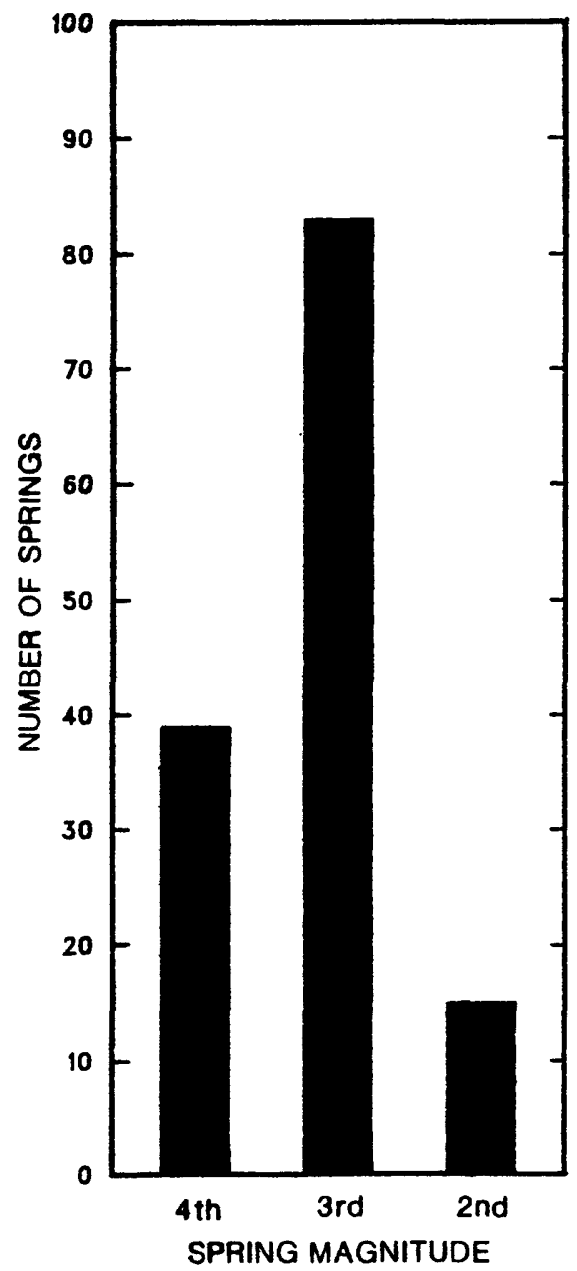




\section{TYPES OF SPRINGS}

The two end-member types of flow systems important in describing the springs of the Valley and Ridge physiographic province are "diffuse" and "conduit". Most springs have characteristics of both flow systems (Shuster and White, 1971; White, 1969). Diffuse flow systems are characterized by a network of interconnected openings, typically only a fraction of an inch wide, that transmit water slowly. Conduit flow systems are characterized by a few large interconnected openings, such as those that develop in solution-enlarged openings in carbonate rocks. The enlarged openings may be connected to smaller openings. Conduits receive and transmit water freely. Diffuse flow systems respond slowly to precipitation events, whereas conduit flow systems respond quickly (Shuster and White, 1972).

The type of rock from which a spring discharges can sometimes be used to infer the lithology in which the ground-water reservoir, that feeds the spring, has developed. For many springs, most of the water may be coming from an overlying or underlying aquifer that may have a lithology different from that from which the spring discharges. Most of the large springs in the Valley and Ridge physiographic province of Pennsylvania discharge from carbonate rocks. These springs account for 90 percent (123 out of 137) of the springs reported in table 2 (at back of report). Diffuse or conduit flow systems can form in carbonate rocks, but the largest springs are associated with the conduit type of flow system. Some of the largest springs in the Valley and Ridge physiographic province are associated with very large conduits in the form of caves. Because caves are mostly above the water table, they are the extreme end-member and last, highly modified, stage in the development of a conduit flow system. Penn's Cave Spring (Ce 3 ) in Centre County is a good example of conduit flow in a cave. Penn's Cave Spring discharges about 4,000 gal/min and flows through a cavern that is large enough to be toured by boat.

Noncarbonate rocks, such as sandstone and shale, also can be the source of some fairly large springs. Diffuse flow systems are the dominant type in this kind of rock. Nine of the large springs in the Valley and Ridge physiographic province discharge from clean sandstone and three from shale and other interbedded rock types. The largest measured discharge for a spring discharging from a clean sandstone is $1,800 \mathrm{gal} / \mathrm{min}$ for Spring Meadow Spring (Bd 4) in Bedford County, and the largest measured discharge for a spring discharging from shale or other interbedded rock types is $530 \mathrm{gal} / \mathrm{min}$ for an unnamed spring (Fr 12) in Franklin County.

Two of the large springs in the Valley and Ridge physiographic province of Pennsylvania discharge from unconsolidated materials. An unnamed spring in Monroe County (Mo 1) issues from glacial drift and discharges $650 \mathrm{gal} / \mathrm{min}$. Muffley Spring (Np 4) in Northampton County discharges from a glacial moraine at $200 \mathrm{gal} / \mathrm{min}$. These two springs account for slightly more than 1 percent of the large springs reported. 


\section{SOURCE OF DATA}

Data selected for this report were compiled from published and unpublished reports of the U.S. Geological Survey. Additional data not included in this report are stored in the Ground-Water site Inventory data base of the U.S. Geological Survey in Pennsylvania. Information on all of the springs in the Pennsylvania data base is available from the Pennsylvania district offices of the U.S. Geological Survey, Water Resources Division.

\section{SUMMARY}

Information for 137 large springs in the Valley and Ridge physiographic province of Pennsylvania has been tabulated to summarize the data useful to the U.S. Geological Survey's APRASA (Appalachian Valleys--Piedmont Regional Aquifer-System Analysis) study. This information includes spring number, latitude, longitude, spring name, owner, aquifer, water use, date of discharge measurement, method of discharge measurement, and individual discharge values. The springs have been classified into magnitudes on the basis of the value of a single instantaneous discharge measurement or the median value for multiple instantaneous discharge measurements. A frequency distribution of the magnitude of springs has been determined. Among the springs measured or estimated to date (1989), 39 springs are fourth magnitude, 83 are third magnitude, 15 are second magnitude, and none are first magnitude in the Valley and Ridge physiographic province of Pennsylvania. The largest of the secondmagnitude springs include Big Spring (Cumberland County), Boiling Spring, Forked Spring, Mammoth Spring (Mifflin County), and Nippono Spring. Most of the large springs discharge from carbonate rocks (123 out of 137), 9 discharge from clean sandstone, 3 from shale and other interbedded rock types, and 2 from unconsolidated material. 


\section{SELECTED REFERENCES}

Flippo, H.N. Jr., 1974, Springs of Pennsylvania: Pennsylvania Department of Environmental Resources, Water Resources Bulletin 10, 46 p.

Koester, H.E., and Miller, D.R., 1982, Ground-water quality and data on wells and springs in Pennsylvania, Volume II--Susquehanna and Potomac River Basins: U.S. Geological Survey Open-File Report 81-329, 131 p.

Lloyd, O.B., and Carswe11, L.D., 1981, Groundwater resources of the Williamsport region, Lycoming County, Pennsylvania: Pennsylvania Geological Survey, 4th ser., Water Resources Report 51, 68 p.

Lohman, S.W., 1937, Ground water in Northeastern Pennsylvania: Pennsylvania Geological Survey, 4th ser., Water Resources Report 4, 312 p.

.... 1938, Ground water in south-central Pennsylvania: Pennsylvania Geological Survey, 4th ser., Water Resources Report 5, 315 p.

- Meinzer, O.E., 1927, Large springs in the United States: U.S. Geological Survey Water-Supply Paper 557, 94 p.

Royer, D.W., 1983, Summary groundwater resources of Lebanon County, Pennsylvania: Pennsylvania Geological Survey, 4th ser., Water Resources Report 55, 84 p.

Shuster, E.T., and White, W.B., 1971, Seasonal fluctuations in the chemistry of limestone springs--A possible means for characterizing carbonate aquifers: Journal of Hydrology, v. 14, p. 93-128.

-... 1972, Source areas and climatic effects in carbonate groundwaters determined by saturation indices and carbon dioxide pressures: Water Resources Research, v. 8, no. 4, p. 1067-1073.

Taylor, L.E., Groundwater resources of the upper Susquehanna River basin, Pennsylvania: Pennsylvania Geological Survey, 4th ser., Water Resources Report 58, $136 \mathrm{p}$.

Taylor, L.E., and Werkheiser, W.H., 1984, Groundwater resources of the lower Susquehanna River basin, Pennsylvania: Pennsylvania Geological Survey, 4 th ser., Water Resources Report 57, 130 p.

Taylor, L.E., Werkheiser, W.H., duPont, N.S., and Kriz, M.L., 1982, Groundwater resources of the Juniata River basin, Pennsylvania: Pennsylvania Geological Survey, 4th ser., Water Resources Report 54, $131 \mathrm{p}$.

Taylor, L.E., Werkheiser, W.H., and Kriz, M.L., 1983, Groundwater resources of the West Branch Susquehanna River basin, Pennsylvania: Pennsylvania Geological Survey, 4th ser., Water Resources Report 56, 143 p. 


\section{SELECTED REFERENCES--Continued}

White, W.B., 1969, Conceptual models for carbonate aquifers: Ground Water, v. 7 , no. 3 , p. 15-21.

Wood, C.R., and MacLachlan, D.B., 1978, Geology and groundwater resources of northern Berks County, Pennsylvania: Pennsylvania Geological Survey, 4th ser., Water Resources Report 44, 91 p. 
Table 2.--Records of the large springs in the Valley and Ridge physiographic province of Pennsylvania

[Discharge in gallons per minute; --, no data avallable]

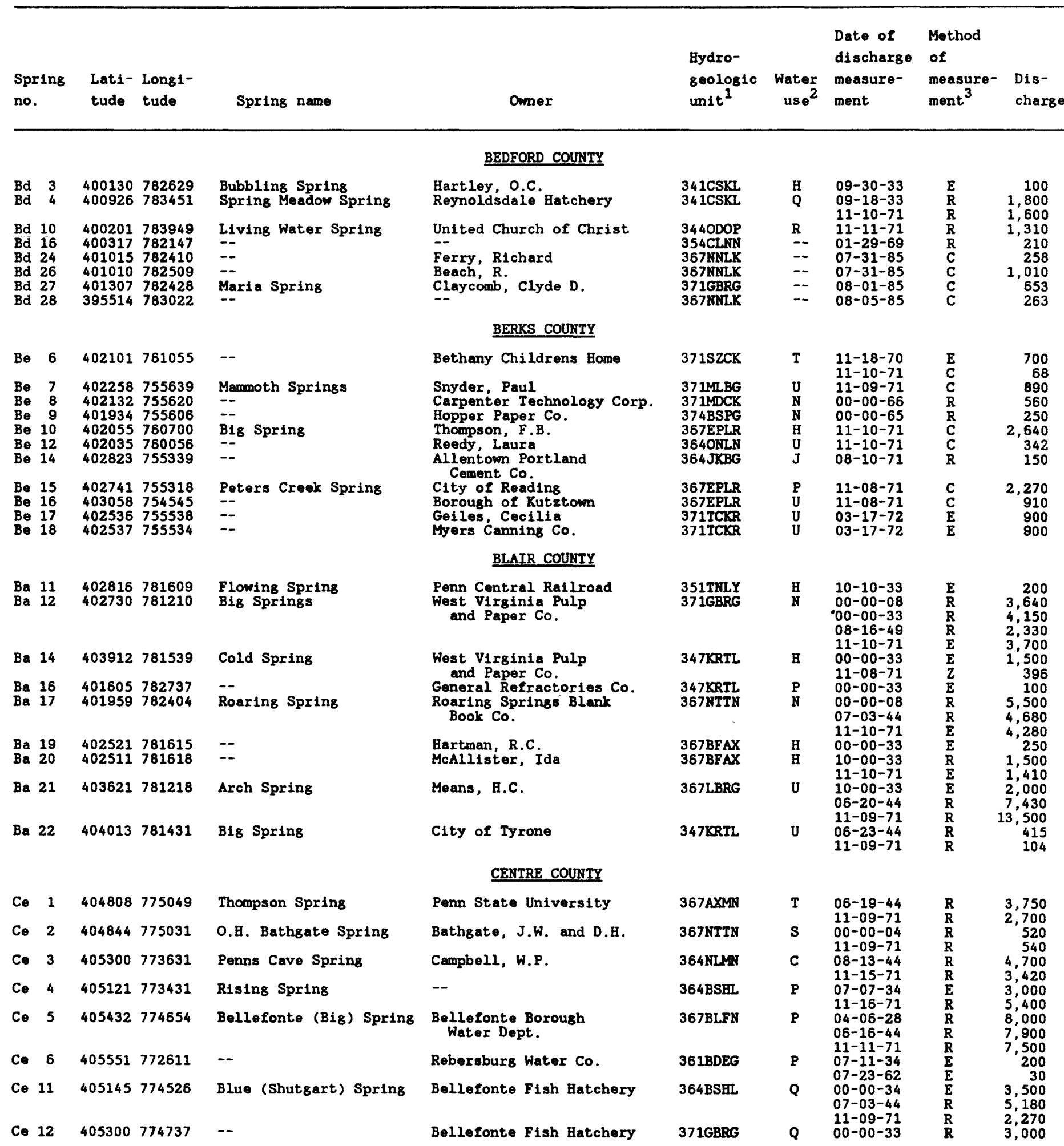


Table 2.--Records of the large springs in the Valley and Ridge physlographic province of Pennsylvania

[Discharge in gallons per minute; --, no data avallable]

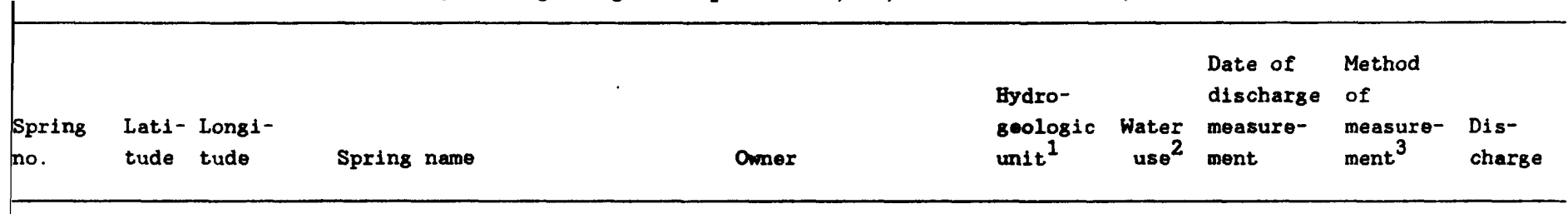

CENTRE COUNTY--Continued

Ce 14404221775805 Rock Spring

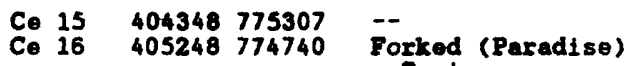
Spring

\begin{abstract}
Fry Estate
\end{abstract}
Bellefonte Fish Eatchery

White, B.C.

Benner Research Station

IItan Mfg. Co.

$--$

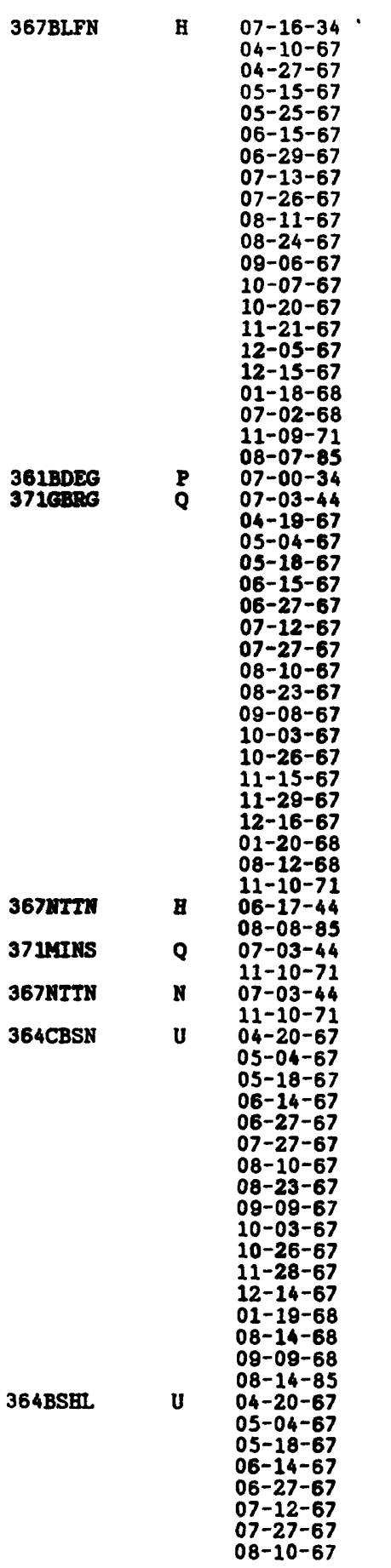

1,000

5,400

9,450

4,810

5,400

1,750

1,530

1,530
3,150

3,150
1,800

900

315
225

2,650

2,650
1,120

1,120
1,480

1,480
11,200

3,370

1,350

1,710

333

120
2,580

18,000

16,600

18,400

13,900

13,500

13,000
13,900

13,900

13,000

10,800

12,100

13,500

13,500

12,600

11,700

11,200

- 10,300

3,930

2,030

943
7,300

4,080

7,000

8,600

8,600
3,150

3,150

4,950

3,150

1,350

4,500

5,400

3,600

1,350

1,350

13,500

5,400

8,100

8,100
1,800

1,800
900

450

392

788

918

932

527

450

459

279 
Table 2.--Records of the large springs in the Valley and Ridge physiographic province of Pennsylvanis

[Discharge in gallons per minute; --, no data avallable]

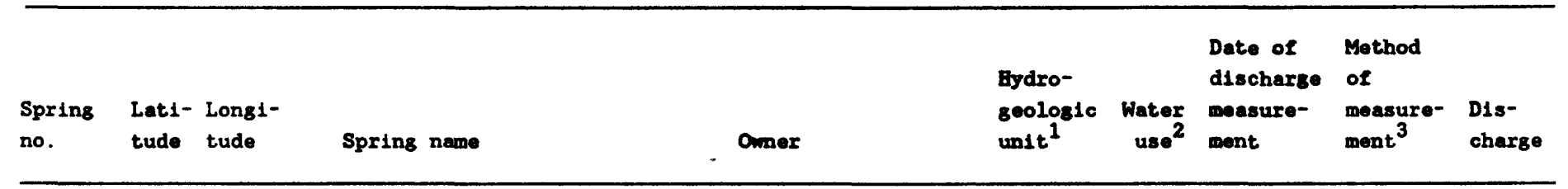

Ce 24--Continued

Ce 25405525772904 Spring Bank

Ce 32404730774454 ;

Cn $2410324772811 \ldots$

$\begin{array}{lllll}C n & 3 & 410504 & 772728 & \text { B18 Spring }\end{array}$

$\mathrm{Cn} 4 \quad 410145771840 \quad$ Kemmerer Spring

Cn 7410002773203 Steel Spring

Cn 8410059773150

Cn $11 \quad 410013773201$

Cn $12 \quad 410258 \quad 773132$

Washington Furnace

$$
\text { Spring }
$$

Cedar Spring

Cn $13 \quad 410248773148 \quad-$

Cn $14 \quad 410312773103$ Lamey Spring

Cn $15 \quad 410317773058 \quad$ Crystal Spring

Cn $16 \quad 410322773055 \quad$ McLane Spring

Cn 17405857772800 Ruhl Spring

Cn 18405857772800 Seven Springs

Cn 19. 410058773152 Lamar Spring

Cn 21405938772503

Cn $24 \quad 410145771844 \quad-$

Cu $1401419765708 \quad$--

Cu 2401344765514 Eichelberger Spring

Cu $3401339765507 \quad$ Spring Lake Spring

Cu $4 \quad 401428770025$ Silver Spring
$--$

\section{CENIRE COUNTY--Continued}

(a)

Bickle, Cindy

\section{CLINTON COUNTY}

Valley Dairy

Cedar Spring Fish

Batcheries

Kenmerer, Jolm

U.S. Bureau of Fisheries

Gribe, C.B.

U.S. Bureau of Fisheries

\section{Tomalomis}

Long, J.F.

Lamey, Jom

Pa. Fish Commission

$-$

U.S. Bureau of Fisheries

U.S. Bureau of Fisheries

-.

$-$

$-$

\section{CUMBERLAND COUNTY}

Hampden Township

Toray Investment Co.

Weaver, Marlin

Silver Spring Prsbytrn. Church

$11-06-70$
$11-11-71$

$\begin{array}{cc} & 08-23-67 \\ 09-09-67 \\ 10-03-67 \\ 10-26-67 \\ 11-14-67 \\ 01-19-68 \\ 06-21-68 \\ 08-00-74 \\ 08-15-85 \\ 04-20-67 \\ 05-04-67 \\ 05-18-67 \\ 06-14-67 \\ 06-27-67 \\ 07-12-67 \\ 07-27-67 \\ 08-10-67 \\ 08-23-67 \\ 09-09-67 \\ 10-03-67 \\ 10-26-67 \\ 11-14-67 \\ 11-28-67 \\ 12-14-67 \\ 01-19-68 \\ 05-30-68 \\ & 08-07-85\end{array}$

\begin{tabular}{lr}
$\mathbf{R}$ & 374 \\
$\mathbf{R}$ & 225 \\
$\mathbf{R}$ & 608 \\
$\mathbf{R}$ & 752 \\
$\mathbf{R}$ & $\mathbf{2 , 4 0 0}$ \\
$\mathbf{R}$ & 256 \\
$\mathbf{R}$ & 383 \\
$\mathbf{R}$ & 450 \\
$\mathbf{R}$ & 126 \\
$\mathbf{R}$ & 1,290 \\
$\mathbf{R}$ & 1,200 \\
$\mathbf{R}$ & 900 \\
$\mathbf{R}$ & 563 \\
$\mathbf{R}$ & 580 \\
$\mathbf{R}$ & 405 \\
$\mathbf{R}$ & 275 \\
$\mathbf{R}$ & 738 \\
$\mathbf{R}$ & 270 \\
$\mathbf{R}$ & 383 \\
$\mathbf{R}$ & 315 \\
$\mathbf{R}$ & 2,070 \\
$\mathbf{R}$ & 1,800 \\
$\mathbf{R}$ & 900 \\
$\mathbf{R}$ & 1,260 \\
$\mathbf{R}$ & 414 \\
$\mathbf{R}$ & 1,030 \\
$\mathbf{C}$ & 2,490 \\
\hline
\end{tabular}

\begin{tabular}{|c|c|c|}
\hline 367BLFA & $\mathbf{u}$ & $\begin{array}{l}07-25-34 \\
11-11-71 \\
08-13-85 \\
07-30-34\end{array}$ \\
\hline $\begin{array}{l}\text { 367BLFH } \\
\text { 364BSEL } \\
367 \mathrm{BLFN} \\
\text { 367BLFN }\end{array}$ & $\begin{array}{l}\mathbf{S} \\
\mathbf{Q} \\
\mathbf{B} \\
\mathbf{Q}\end{array}$ & $\begin{array}{l}07-20-34 \\
00-00-33 \\
08-13-85 \\
07-04-44 \\
11-09-71\end{array}$ \\
\hline 367AXMin & $\mathbf{z}$ & $\begin{array}{l}07-04-44 \\
11-10-71 \\
08-12-85\end{array}$ \\
\hline $\begin{array}{l}\text { 3678LFN } \\
367 A X N 1 \\
367 A X N N\end{array}$ & $\begin{array}{l}\mathbf{Q} \\
\mathbf{U} \\
\mathbf{Q}\end{array}$ & $\begin{array}{l}11-10-71 \\
11-10-71 \\
07-04-44 \\
11-10-71 \\
08-12-85\end{array}$ \\
\hline $367 \mathrm{AXMN}$ & $\mathbf{U}$ & $\begin{array}{l}07-04-44 \\
11-10-71 \\
08-12-85\end{array}$ \\
\hline $\begin{array}{l}364 \mathrm{CBSN} \\
364 \mathrm{CBSN} \\
367 \mathrm{BLFN}\end{array}$ & $\begin{array}{l}\mathbf{Q} \\
\mathbf{Q} \\
\mathbf{U}\end{array}$ & $\begin{array}{l}07-04-44 \\
07-04-44 \\
08-13-44 \\
11-09-71\end{array}$ \\
\hline 364BSHL & $\mathrm{U}$ & $\begin{array}{l}11-10-71 \\
08-14-85 \\
08-15-85\end{array}$ \\
\hline
\end{tabular}

2, 000

4,000

2,060

1,000

300

2,000

1,450

1,760

1,870

1,000

1,440

1,070

570

9.170
3.170

4,170
3,700

3,700
2,940

890

670

5. 100

5,900

5,900
1,440

1,100

13,000

1,290

100

361MRBG U 04-13-70

364STPL U 11-12-71

I1-12-71

364 STPL I 11-06-7

367RCKR

$11-12-71$
$11-06-70$

$\begin{array}{lr}\mathbf{E} & 450 \\ \mathbf{R} & 350 \\ \mathbf{C} & 1,450 \\ \mathbf{R} & 990 \\ \mathbf{R} & 420 \\ \mathbf{R} & 290 \\ \mathbf{C} & 1,690 \\ \mathbf{C} & 1,890\end{array}$


Table 2.--Records of the large springs in the Valley and Ridge physiographic province of Pennsylvania

[Discharge in gallons per minute; --, no data available]

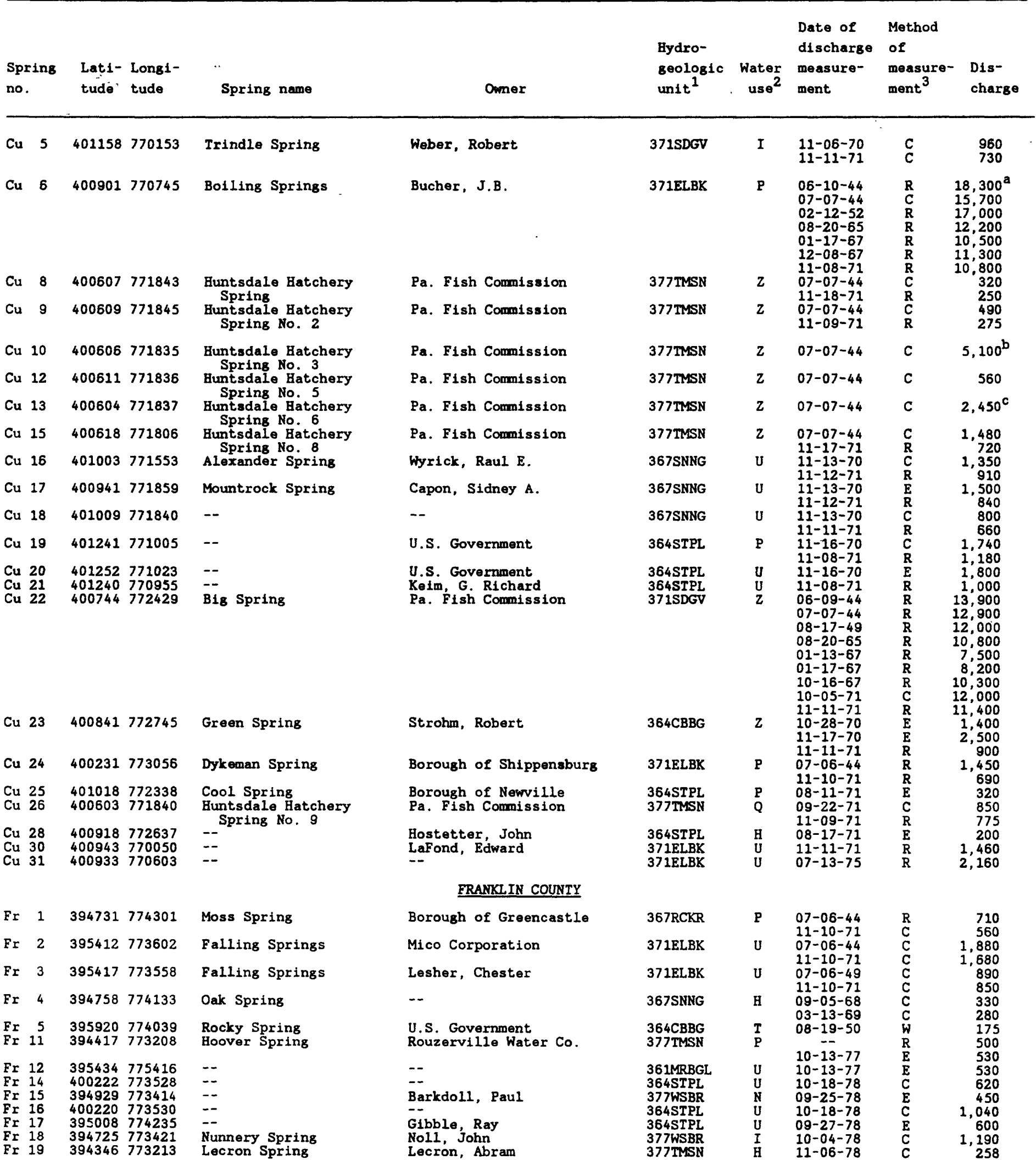


Table 2.--Records of the large springs in the Valley and Ridge physiographic province of Pennsylvanis

[Discharge in gallons per minute; --, no data avallable]

\begin{tabular}{|c|c|c|c|c|c|c|c|c|}
\hline $\begin{array}{l}\text { Sprins } \\
\text { no. }\end{array}$ & $\begin{array}{l}\text { Lat I- Lons1- } \\
\text { tude tude }\end{array}$ & Sprins name & Omer & $\begin{array}{l}\text { Eydro- } \\
\text { seolostc } \\
\operatorname{mit}^{1}\end{array}$ & $\begin{array}{l}\text { Water } \\
\text { use }\end{array}$ & $\begin{array}{l}\text { Date of } \\
\text { dischare } \\
\text { measure- } \\
\text { ment }\end{array}$ & $\begin{array}{l}\text { Method } \\
\text { of } \\
\text { measure- } \\
\text { ment }{ }^{3}\end{array}$ & $\begin{array}{l}\text { D1s- } \\
\text { charge }\end{array}$ \\
\hline
\end{tabular}

\section{ERAJirI covitr--Continued}

$\begin{array}{lllll}\text { Fr } 20 & 395222 & 775605 & -- \\ \text { Fr } 21 & 385014 & 775538 & -- \\ \text { Fr 22 } & 395021 & 775132 & -- \\ \text { Fr } 23 & 394342 & 773950 & \text { Big Spring }\end{array}$

Fu $1395036780205 \quad$ Bis Spring

\begin{tabular}{|c|c|c|c|c|}
\hline $\begin{array}{l}\text { Bu } \\
\text { Hu }\end{array}$ & $\frac{1}{2}$ & $\begin{array}{l}403919 \\
404132\end{array}$ & $\begin{array}{l}781210 \\
780143\end{array}$ & $\begin{array}{l}\text { Bundred Spring } \\
\text { Double Spring }\end{array}$ \\
\hline Bu & 4 & 403252 & 775827 & Warm Sprins \\
\hline Hu & $\mathbf{9}$ & 402935 & 780140 & Prices Spring \\
\hline Hu & 10 & .401743 & 780933 & - \\
\hline H & 12 & 403702 & 780754 & Spruce Creek \\
\hline
\end{tabular}

Hu 13403408780924 Tippery Cave Spring

Bu $14 \quad 403406780924$ Near Tippery Spring

\begin{tabular}{|c|c|c|c|c|}
\hline Lb & 18 & 401948 & 762945 & Penryth Spring \\
\hline $\mathbf{L b}$ & 52 & 401924 & 761551 & - \\
\hline $\begin{array}{l}\text { Le } \\
\text { Le } \\
\text { Le }\end{array}$ & $\begin{array}{l}14 \\
15 \\
17\end{array}$ & $\begin{array}{l}403543 \\
403447 \\
403526\end{array}$ & $\begin{array}{l}752853 \\
753318 \\
752908\end{array}$ & $\begin{array}{l}\text { Crystal Spring } \\
\text { Schantz Spring } \\
\text { 15th Street Spring }\end{array}$ \\
\hline Le & 65 & 403741 & 752929 & Helfrich's Spring \\
\hline $\begin{array}{l}\text { Le } \\
\text { Le } \\
\text { Le }\end{array}$ & $\begin{array}{l}66 \\
71 \\
78\end{array}$ & $\begin{array}{l}403440 \\
403533 \\
403353\end{array}$ & $\begin{array}{l}753238 \\
753203 \\
753049\end{array}$ & $\begin{array}{l}\text { Poorhouse Spring } \\
\text { Trexler Spring } \\
\text { Fish Hatchery Spring }\end{array}$ \\
\hline 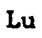 & 8 & 410200 & 755419 & -- \\
\hline
\end{tabular}

\section{Rtce, Richard \\ Johnston, Thomas $\mathrm{B}$. \\ $-$ \\ EULTON COUnTY}

Norton, D.M.

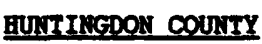

Grier Waterworks

Grier Waterworks

Layne, Dr. A.

state of $\mathrm{Pa}$.

$-$

$--$
Lu $8 \quad 410200755419$
367PES:

36401:5

367Pies

3675igs

364BKax

367 mitux

367NTT

347RDEL

$347 R D C L$

$327 x \mathrm{ccc}$

367NNLK

(1)

367BPA

$-$

\section{LEBANON COUNTY}

Annville Water Co.

Zimmerman, Abraham

\section{LEHIGH COUNTY}

City of Allentown

City of Allentown

City of Allentown

McCready, Horace

Lehigh County

Lehigh County

City of Allentown

\section{LUZERNE COUNTY}

Freeland Water Co.

67EPT

371SZCK
371SR

\section{ALNA}

364 BKAN

37 1ALNA

367EPLR

371ALNM

37 IALNM

37 IALNA

327 MCCK

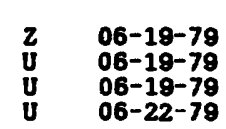

$\begin{array}{lr}C & 430 \\ M & 525 \\ C & 1,300 \\ C & 2,500\end{array}$

10-13-33

E

500

2,800

500

420
750

750

243

585
690

25

1,350

2,290

2,700

3,730

2, 340

2,110

1.750

1,930

1,750

585
1,260

1,260
1,080

1,480

2,110

1,350

720

1,300

1,350

1,710

$\begin{array}{lll}05-15-67 & R & 1,350 \\ 07-26-67 & R & 1,710 \\ 12-15-67 & \text { R } & 1,300\end{array}$

$-$

07-11-61

$\begin{array}{lr}\mathbf{E} & \mathbf{1 , 0 0 0} \\ \mathbf{R} & \mathbf{5 2 5} \\ \mathbf{E} & 100\end{array}$

B

1,400 5,000

50
470

800

975

170

125
200 
Table 2.--Records of the large springs in the Valley and Ridge physiographic province of Pennsylvania

[Discharge in gallons per minute; --, no data available]

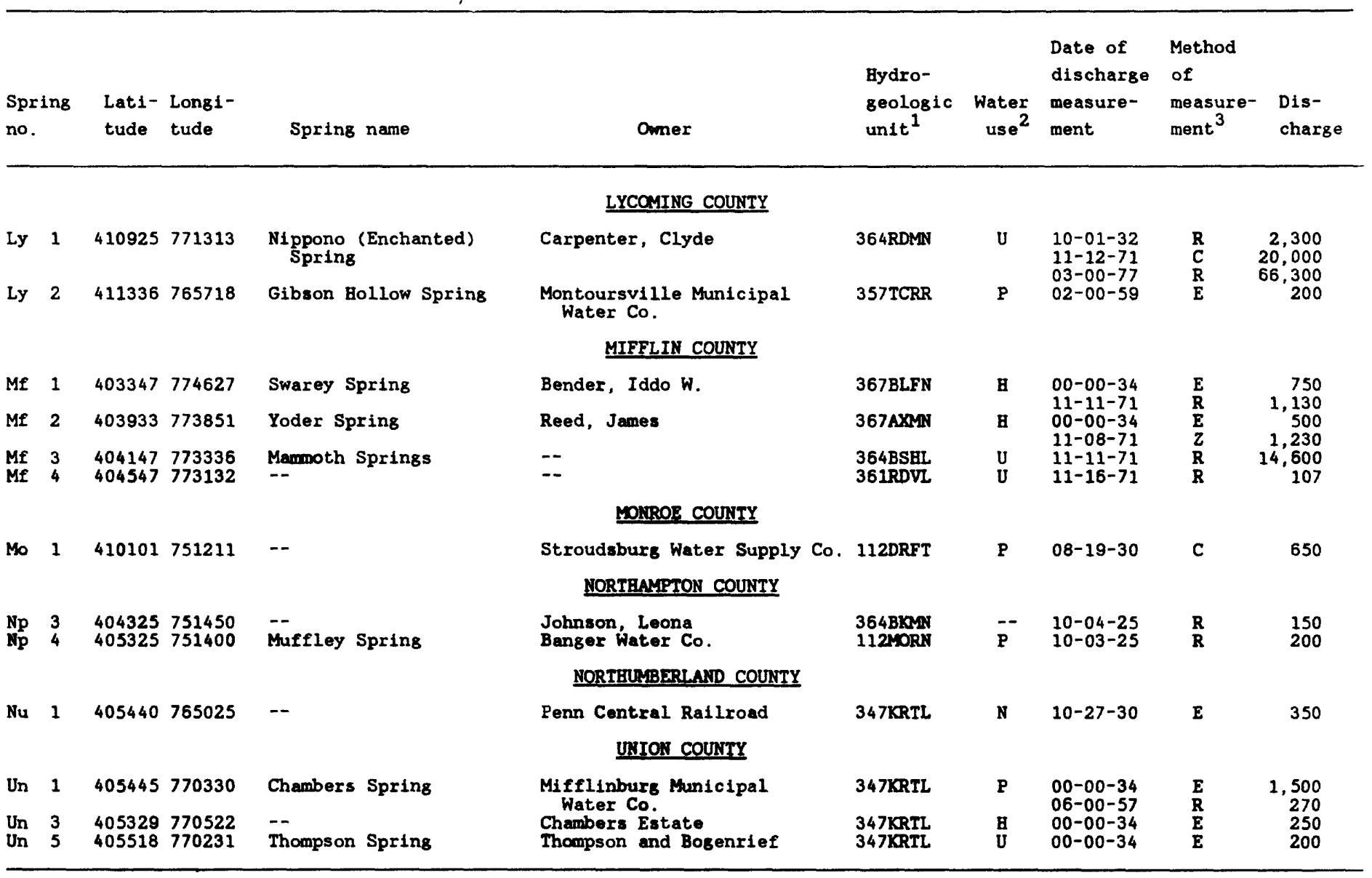

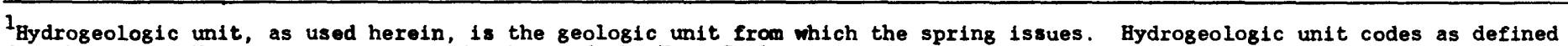
for the Ground-Water Site Inventory database of the U.S. Geological Survey, Pennsylvania district: 112DRFT=drift;

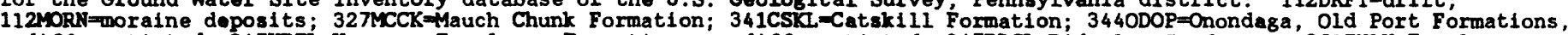
undifferentiated; 347KRTL-Keyser, Tonoloway Formations, undifferentiated; 347RDGL=Ridgeley Sandstone; 351TNLY=Tonoloway

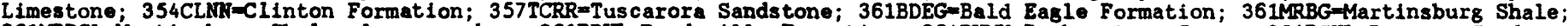

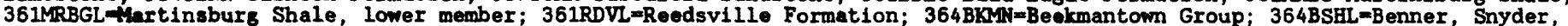

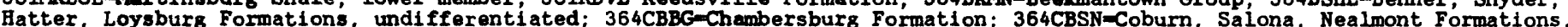
undifferentiated; $364 \mathrm{JKBG}-\mathrm{Jacksonburs}$ Formation; $364 \mathrm{NLN}$-Nealmont Formation; 364ONLN-Ontelaunee Formation; 364RDMN=Rodman Limestone; 364STPL $=$ St. Paul Group; $367 \mathrm{AXMN}=A x e m a n n$ Formation; $367 B F A X=A x e m a n n$, Bellefonte Formations, undifferentiated; 367BLFN $=$ Bell econte Formation; 367EPLR=Epler Formation; 367LBRG-Loysburg Formation; 367NNLK=Nittany, Larke Formations, undifferentiated; 367NTTN=N1t tany Formation; 367PBGS=Pinesburg Station Dolomite; $367 R C K R=R o c k d a l e ~ R u n$ Formation; 367SFRS $=$ Stoufferstown Formation; 367SWNG-Stonehenge Formation; 371ALMN=Allentown Formation; 371ELBK $=E 2 b r o o k$ Formation; 371GBRG=Gatesburg Formation; 371MDCK=Allentown Formation, Maiden Creek Member; 371MINS=Mines Formation; 371MLBG=Allentown Formation, Muhlenberg Member; 371SDGV=Shadygrove Formation; 371SZCK=Snitz Creek Formation; 371TCKR=Allentown Formation, Tuckerton Member; 374BSPG=Buffalo Springs Formation; 377THSN=Tomstown Formation; 377WSBR=Waynesboro Formation.

2water use codes as defined for the Ground-Water Site Inventory database of the U.S. Geological Survey, Pennsylvania

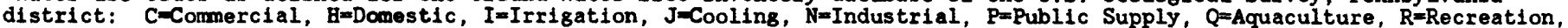
$S=$ Stock supply, $T=$ Institutional, Ununused, $Z=0$ ther.

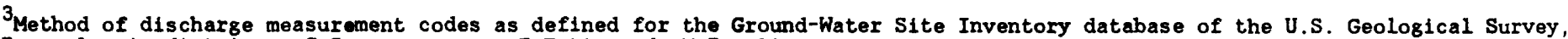
Pennsylvania district: C-Current meter, E=Estimated, M-Totaling meter, $R=R e p o r t e d, W=W e i r, Z=0 t h e r$.

apeported discharge includes flow from Cu 7 (Boiling Springs).

beported discharge includes flow from Cu 11 (Huntsdale Batchery Spring No. 4).

${ }^{C}$ Reported discharge includes flow from Cu 14 (Buntsdale Hatchery Spring No. 7). 